\title{
A Review of Recent Advances Using Tocilizumab in the Treatment of Rheumatic Diseases
}

\author{
Andrea Rubbert-Roth - Daniel E. Furst - Jan Michael Nebesky · \\ Angela Jin · Erhan Berber
}

Received: December 15, 2017 / Published online: March 3, 2018

(C) The Author(s) 2018. This article is an open access publication

\begin{abstract}
Tocilizumab (TCZ) is the first humanized antiinterleukin-6 (IL-6) receptor monoclonal antibody approved for the treatment of patients with rheumatoid arthritis (RA), Castleman's disease, polyarticular and systemic juvenile idiopathic arthritis, and, most recently, giant cell arteritis as well as for the treatment of chimeric antigen receptor $\mathrm{T}$ cell therapy-induced
\end{abstract}

Enhanced content To view enhanced content for this article go to https://doi.org/10.6084/m9.figshare. 5903623.

\author{
A. Rubbert-Roth $(\square)$ \\ Kantonsspital St Gallen, St Gallen, Switzerland \\ e-mail: Andrea.Rubbert-Roth@kssg.ch \\ D. E. Furst \\ University of California, Los Angeles, Los Angeles, \\ CA, USA \\ D. E. Furst \\ University of Washington, Seattle, WA, USA \\ D. E. Furst \\ University of Florence, Florence, Italy \\ J. M. Nebesky \\ F. Hoffmann-La Roche, Basel, Switzerland \\ A. Jin · E. Berber \\ Genentech, South San Francisco, CA, USA \\ Present Address: \\ A. Rubbert-Roth \\ Clinic for Rheumatology, Kantonsspital St. Gallen, \\ St. Gallen, Switzerland
}

cytokine release syndrome. The global clinical development program for TCZ provides a wealth of clinical data on intravenous TCZ, and more recent studies in patients with RA have provided evidence characterizing the role of intravenous TCZ as monotherapy in early disease and led to the introduction of a subcutaneous formulation of TCZ. In addition, recently published open-label extension and observational studies continue to support the longterm efficacy and safety of TCZ in both clinical trial and real-world settings. Given the involvement of IL-6-mediated signaling in inflammatory disorders, TCZ is also being investigated in other immunological diseases. In particular, a phase 2 trial on the safety and efficacy of subcutaneous TCZ in adults with systemic sclerosis shows clinically relevant improvements in skin sclerosis and lung function in these patients. Another anti-IL-6 receptor agent, sarilumab, targeting the IL6 receptor alpha subunit, was recently approved for the treatment of patients with RA, although longterm data for this biologic are not yet published. In this article we review the placement of TCZ in current treatment guidelines; recent clinical trial data, including quality of life in patients with RA; recent updates to the TCZ safety profile; recent investigations of $\mathrm{TCZ}$ in other immunological diseases; and the clinical development of other novel IL-6-targeted agents. 
Keywords: Interleukin-6; Rheumatoid arthritis; Tocilizumab

\section{TOCILIZUMAB: THE FIRST INTERLEUKIN-6 RECEPTOR- NEUTRALIZING BIOLOGIC}

Interleukin-6 (IL-6) is a multifunctional cytokine that plays an important role in both acute and chronic inflammatory responses. Consequently, the dysregulated or persistent production of IL-6 can lead to the development of inflammatory disorders [1]. Elevated levels of IL6 in serum, synovial fluid, and various tissues have been correlated with disease activity in patients with rheumatoid arthritis (RA) [2], juvenile idiopathic arthritis (JIA) [3, 4], Castleman's disease [5, 6], systemic sclerosis (SSc) [7], giant cell arteritis (GCA) [8, 9], adult-onset Still's disease (AOSD) [10], familial Mediterranean fever (FMF) [11, 12], Schnitzler's syndrome [13, 14], polychondritis [15], and amyloidosis [1]. These associations suggest a pathogenetic role for IL-6 in multiple inflammatory conditions and form the basis of the rationale for the development of anti-IL- 6 therapies.

Tocilizumab (TCZ) is the first humanized monoclonal antibody targeting the IL- 6 receptor subunit alpha (IL-6R $\alpha$ ) [16], and its mechanism of action has been described in detail in previous reviews $[17,18]$. Briefly, TCZ targets both membrane-bound and soluble IL-6R $\alpha$, which prevents the binding of IL- 6 to both the IL-6R and the signal transducer glycoprotein 130 complex and results in turn in inhibition of the downstream classic signaling and trans-signaling cascades involving the Janus-activated kinase-signal transducer and activator of transcription (JAK-STAT) pathway (Fig. 1) [1, 19]. Through this mechanism, TCZ decreases the circulating levels of neutrophils, neutrophil infiltration into inflamed joints [20], circulation of myeloid dendritic cells [21], monocyte levels, serum macrophage migration inhibitory factor levels [21, 22], and levels of T helper 17 (Th17) cells, while increasing regulatory T cells $[23,24]$. TCZ also induces regulatory B-cell expansion, decreases B-cell hyperactivity, and decreases the number of peripheral memory $B$ cells. Immunogenicity to TCZ (antidrug antibodies) is low [25-27].

In this review we briefly summarize the clinical development that supports the approval of TCZ by regulatory authorities for the treatment of Castleman's disease, JIA, and RA that has been reviewed previously. A more detailed review is provided of the placement of TCZ in recent RA treatment guidelines; recent TCZ clinical trial data, including quality of life (QOL) in patients with RA; recent updates to the TCZ safety profile; investigations in recently approved and nonapproved immunological diseases; and the clinical development of novel IL-6-targeted agents.

This article is based on previously conducted studies and does not involve any new studies of human or animal subjects performed by any of the authors.

\section{TCZ: BRIEF OVERVIEW OF DEVELOPMENT FOR USE IN APPROVED INDICATIONS}

The key trials that contributed to the global clinical development of TCZ for use in its approved indications-RA, Castleman's disease, systemic JIA (sJIA), polyarticular JIA (pJIA), and GCA-are shown in Fig. 2.

\section{Castleman's Disease}

In 2005, TCZ was initially approved for the treatment of Castleman's disease in Japan, where it significantly alleviated chronic inflammatory symptoms and wasting and demonstrated good tolerability [16].

\section{Juvenile Idiopathic Arthritis}

The results of Japanese phase 3 trials demonstrated that TCZ effectively treated children with systemic and pediatric JIA (sJIA and PJIA, respectively), as measured by JIA American College of Rheumatology (ACR) response rates. This resulted in its approval for both indications 


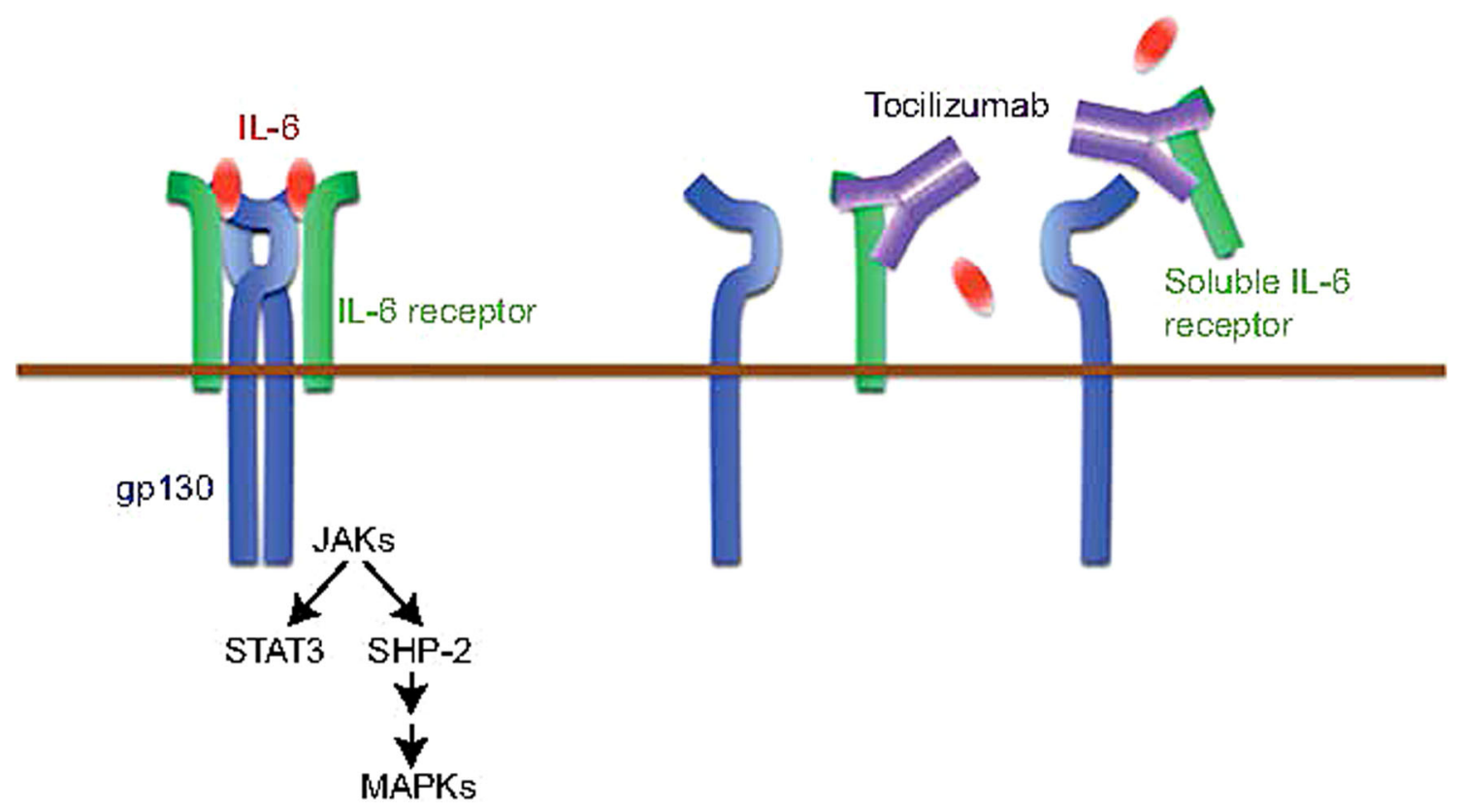

Fig. 1 Interleukin-6 (IL-6) signaling. IL-6 binds to and forms a complex with the IL- 6 receptor and glycoprotein 130 (gp130), resulting in the homodimerization of gp130 and subsequent activation of the signaling system via classic signaling or trans-signaling pathways. The humanized antiIL-6 receptor monoclonal antibody tocilizumab targets both soluble and membrane-bound IL- 6 receptors, thus

in Japan in 2008 [28, 29]. In 2011, TCZ was approved in the USA and the European Union (EU) for the treatment of sJIA, and in 2013, for the treatment of pcJIA based largely on phase 3 data from the TENDER and CHERISH trials, in which the signs and symptoms of sJIA and pcJIA, respectively, were improved in children treated with TCZ compared to placebo $[30,31]$.

\section{Giant Cell Arteritis}

Tocilizumab was approved for the treatment of patients with GCA, a vasculitis of medium- and large-sized arteries, by the U.S. Food and Drug Administration (FDA) on 22 May 2017 and by the European Commission on 22 September 2017, making this the first drug approved for the treatment GCA beyond glucocorticoids, which are associated with substantial morbidity from glucocorticoid-related complications following prolonged use [32]. inhibiting the binding of IL-6 to both receptors. $J A K$ Janus-activated kinase, MAPKs mitogen-activated protein kinases, $S H P-2$ Src-homology 2 domain-containing protein tyrosine phosphatase, STAT signal transducer and activator of transcription. Reproduced with permission from Tanaka et al. [1]. Copyright Cold Spring Harbor Laboratory Press

Analysis of biopsy specimens from patients with GCA using quantitative real-time PCR identified proinflammatory pathogenic pathways mediated by Th17, which promotes the release of IL-1 $\beta$, IL- 6 , and IL-23 cytokines, and of Th1, which promotes the release of IL-12 cytokines; these cells contribute to the systemic and vascular manifestations of GCA [33]. As a result, biologic therapies targeting these proinflammatory pathways are logical targets for the treatment of GCA.

The published results of a randomized double-blind phase 2 trial of TCZ in patients with GCA were the first to demonstrate the induction and maintenance of remission in a clinical trial setting [34]. Compared to the placebo group, the TCZ group had higher rates of complete remission at week 12 (85 vs. 40\%) and higher relapse-free survival at week 52 (85 vs. $20 \%)$. 


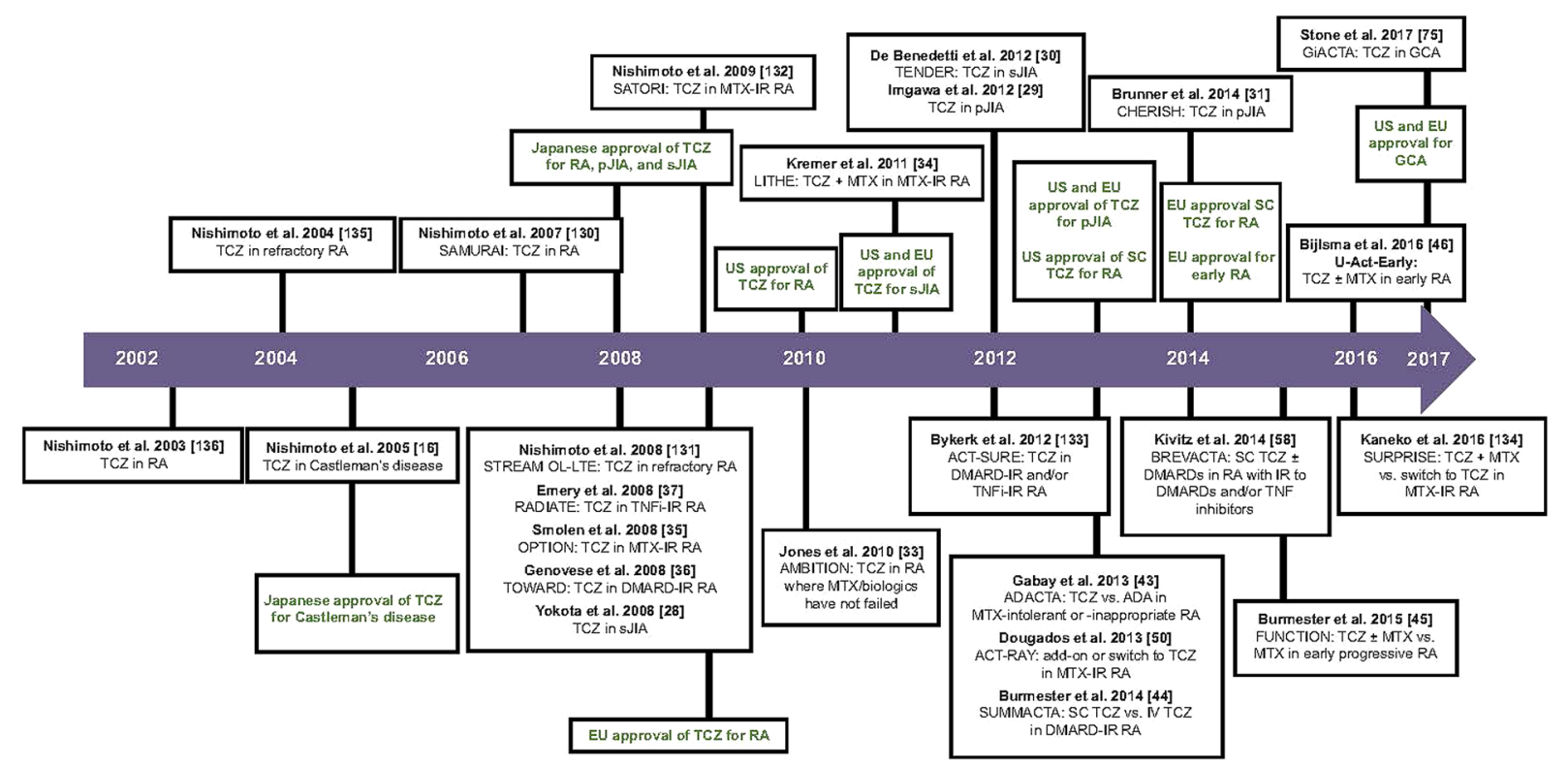

Fig. 2 Global clinical development of tocilizumab ( $T C Z)$ and approval by regulatory authorities for the treatment of inflammatory disorders. DMARD Disease-modifying antirheumatic drug, $E U$ European Union, $G C A$ giant cell arteritis, IR inadequate responder, LTE long-term

Recently, a randomized, double-blind, placebo-controlled, multicenter, phase 3 trial (GiACTA) of TCZ in patients with GCA showed that TCZ + a 26-week prednisone taper was superior to both 26-week and 52-week prednisone tapers alone for the achievement of sustained remission from GCA [35]. Sustained remission at 12 months was achieved by $56 \%$ of patients receiving weekly TCZ +26 -week prednisone taper and $53.1 \%$ of those receiving every-other-week TCZ +26 -week prednisone taper, compared with $14 \%$ of patients receiving the 26 -week prednisone taper alone $(P<0.0001$ for both comparisons). Both TCZ groups were also superior to the 52-week prednisone taper alone group in terms of sustained remission from GCA $(P \leq 0.0002)$. The addition of TCZ to prednisone treatment in the GiACTA trial also allowed a reduction in the cumulative prednisone doses required for disease control, with a median cumulative steroid exposure of 1862.0 $\mathrm{mg}$ in both TCZ groups compared with 3817.5 $\mathrm{mg}$ in the 52-week prednisone taper group and $3296.0 \mathrm{mg}$ in the 26-week prednisone taper extension, $M T X$ methotrexate, $O L$ open-label, $p J I A$ polyarticular juvenile idiopathic arthritis, $R A$ rheumatoid arthritis, $S C$ subcutaneous, $s J A$ systemic juvenile idiopathic arthritis,TNFi tumor necrosis factor inhibitor, US United States of America

group [35]. Kaplan-Meier analysis of data from GiACTA demonstrated that patients with higher TCZ exposure (i.e., those receiving weekly TCZ) experienced a longer time to first flare of GCA [36].

In summary, TCZ is now approved for the treatment of GCA, and the findings of the GiACTA trial indicate that early initiation of TCZ therapy in patients with GCA allows the reduction of glucocorticoid use and cumulative glucocorticoid dose and achieves a reduced flare rate.

\section{Chimeric Antigen Receptor T-Cell Therapy-Induced Cytokine Release Syndrome}

In August 2017, TCZ was approved by the FDA for the treatment of chimeric antigen receptor (CAR) T-cell therapy-induced cytokine release syndrome [37]. This approval was based on retrospective analysis of pooled data from clinical trials of CAR T-cell therapies for blood cancers [38]. 


\section{Rheumatoid Arthritis}

\section{Early Clinical Development in RA}

The initial clinical development of TCZ for the treatment of RA has been reviewed previously [39]. Five randomized, double-blind, controlled, multicenter, phase 3 , pivotal clinical trials were central to the approval of TCZ by regulatory authorities of TCZ in the EU and the USA for the treatment of RA (Fig. 2) [40-44]. Briefly, OPTION [42] and TOWARD [43] together showed that treatment with TCZ at 4 and $8 \mathrm{mg} /$ $\mathrm{kg}$ body weight in combination with methotrexate (MTX) or other conventional synthetic disease-modifying antirheumatic drugs (csDMARDs) reduced the signs and symptoms of RA in patients who responded inadequately to MTX/csDMARDs alone. The LITHE trial [41] demonstrated a greater inhibition of structural joint damage and greater improvement in physical function with TCZ 4 and $8 \mathrm{mg} / \mathrm{kg}+$ MTX than with MTX alone in patients with RA who were inadequate responders to MTX alone. The RADIATE trial [44] showed that TCZ prescribed at 4 and $8 \mathrm{mg} / \mathrm{kg}$ reduced the signs and symptoms of RA in patients who responded inadequately to treatment with tumor necrosis factor (TNF) inhibitors. The AMBITION trial [40] showed that montherapy with TCZ at $8 \mathrm{mg} / \mathrm{kg}$ was superior to monotherapy with MTX in terms of improving signs and symptoms of RA in patients for whom previous treatment with MTX or biologics had not failed.

\section{Dosing and Dose-Response in RA}

The recommended initial dosing regimen for TCZ in patients with RA differs between the EU and the USA. A starting dosage of TCZ $8 \mathrm{mg} / \mathrm{kg}$ every 4 weeks is recommended in the EU [45], whereas a starting dosage of $4 \mathrm{mg} / \mathrm{kg}$ every 4 weeks is recommended in the USA, with the option of increasing to $8 \mathrm{mg} / \mathrm{kg}$ based on clinical response and at the treating physician's discretion [37].

The five pivotal phase 3 studies of TCZ suggested a possible dose response for TCZ 4 and $8 \mathrm{mg} / \mathrm{kg}$; however, the studies were not powered to detect differences between the two dosing regimens [40-44]. Numerical differences in efficacy outcomes were evident between dosing at TCZ 4 and $8-\mathrm{mg} / \mathrm{kg}$, suggesting that some patients may respond well to TCZ $4 \mathrm{mg} / \mathrm{kg}$.

Real-world data show that a large proportion of patients in the USA increase their TCZ dosage from 4 to $8 \mathrm{mg} / \mathrm{kg}$ soon after initiating treatment. Analysis of data from patients with RA in the comparative-effectiveness CERTAIN substudy nested within the U.S. Corrona Registry revealed patterns of TCZ dose escalation in a real-world setting [46]. Among the patients with RA who initiated TCZ treatment and completed the visits at the predetermined 3- and 6-month time points in this substudy $(N=213), 86$ (40.4\%) remained on the initial dosage of $4 \mathrm{mg} /$ $\mathrm{kg}$ and $110(51.6 \%)$ increased their dosage to $8 \mathrm{mg} / \mathrm{kg}$ by 3 months [46]. Improvements in measures of disease activity and moderate or good European League Against Rheumatism (EULAR) response rates were also observed at 3 and 6 months in both groups, suggesting that flexibility in dosing may be possible [46]. Although the sample size of the Corrona analysis was small, the results are consistent with those from an analysis of U.S. healthcare claims data that included 3600 patients with RA who received TCZ intravenously between January 2016 and April 2017. During this period, 31\% of patients received TCZ $4 \mathrm{mg} / \mathrm{kg}, 42 \%$ received TCZ $8 \mathrm{mg} / \mathrm{kg}$, and $27 \%$ switched between the two dosing regimens over the course of the observation period (83\% switched from 4 to $8 \mathrm{mg} / \mathrm{kg}$ ). Furthermore, data between May 2016 and April 2017 indicated stable dosing patterns over 12 months, with approximately $64 \%$ of patients receiving TCZ $8 \mathrm{mg} / \mathrm{kg}$ (Symphony Health Source Healthcare Analytics claims, unpublished data). Subcutaneous (SC) administration of TCZ was received weekly in $66 \%$ of patients and biweekly in 34\% of patients between January 2016 and April 2017 (Symphony Health Source Healthcare Analytics claims, unpublished data). Although the sample size and methodology for this U.S. claims data analysis differed from that of the Corrona analysis, both analyses indicated that a substantial proportion of patients switched from TCZ $4 \mathrm{mg} / \mathrm{kg}$ to TCZ $8 \mathrm{mg} / \mathrm{kg}$. 
In summary, there is some indication of a dose-response relationship with TCZ, but this does not apply to all patient populations. It is the authors' impression that based on numerical trends, there will be some patients who respond well to the $4 \mathrm{mg} / \mathrm{kg}$ dosing regimen. Although data are sparse, some patients may be able to decrease their dosage from 8 to $4 \mathrm{mg} / \mathrm{kg}$ after a period of disease control.

\section{Update on QOL and Patient-Reported Outcomes in RA}

A systematic literature review of randomized controlled trials of TCZ in patients with RA reported improved physical function and QOL [47]. TCZ was associated with greater improvements in disease-related function (as measured by the Health Assessment Questionnaire Disability Index [HAQ-DI]) and QOL (measured with the 36-Item Short Form Health Survey [SF36]) compared with control treatments (placebo, MTX, or csDMARDs); the odds ratio for improvement in HAQ-DI was 1.4 for controls versus 7.0 in favor of TCZ [47]. Improvements exceeding minimal clinically important differences (MCIDs) were reported for the SF-36 Physical Component Summary (PCS; MCID 5.0), SF-36 Mental Component Summary (MCS; MCID 5.0), and Functional Assessment of Chronic Illness Therapy (FACIT) Fatigue Scale scores (MCID 4.0) [47].

Taken together, data from eight phase 3 or 4 trials also support clinically relevant improvements in HAQ-DI scores (MCID > 0.5). Results from the TCZ treatment groups in these trials were generally statistically significantly better than those in the comparator groups, although improvements in HAQ-DI scores were often observed in the comparator groups as well [48-55]. For example, the ADACTA trial comparing TCZ monotherapy to adalimumab monotherapy demonstrated mean HAQ-DI score improvements of -0.7 for TCZ and -0.5 for adalimumab (difference in adjusted means: $-0.2 ; 95 \%$ confidence interval $[\mathrm{CI}]-0.3$ to 0.0 ; $P=0.0653)$. A higher proportion of TCZ-treated patients than adalimumab-treated patients reported improvement in HAQ-DI scores of at least a MCID of 0.22 (92/163 [56.4\%] vs. 83/162 [51.2\%], respectively), although there was no statistically significant difference [49]. Altogether, improvements in QOL were observed in patients who were MTX naive [51, 52], MTX inadequate responders (or with contraindication or intolerance to MTX) [48, 49, 53], csDMARD inadequate responders [50, 54], and TNF inhibitor inadequate responders [55]. The duration of response reported varied from 24 to 104 weeks, which is in line with the duration of each trial [48-51, 53-55], except for one trial in which improvement in HAQ-DI scores was observed at week 24, but not at weeks 52 or 104 [52].

Changes in the SF-36 PCS and MCS scores have been reported in two phase 3 trials and in a post hoc analysis of the RADIATE trial $[49,51,55]$. The ADACTA trial reported improvements in SF-36 PCS scores of 9.2 for TCZ $8 \mathrm{mg} / \mathrm{kg}$ and 7.6 for adalimumab (both greater than the MCID but not statistically significantly different between treatment groups; $P=0.1641)$; SF-36 MCS scores were 7.9 and 5.0, respectively $(P=0.0497)$ [49]. Similar results were reported for both the FUNCTION and RADIATE trials [51, 55].

Improvements in fatigue, as assessed by the FACIT Fatigue Scale, were observed for both TCZ and adalimumab in the ADACTA trial (adjusted mean change to week 24 was 11.4 for TCZ and 8.9 for adalimumab; difference: 2.5; 95\% CI -0.3 to $5.3 ; P=0.0770$ ) [49] and for TCZ in a post hoc analysis of the RADIATE trial (mean changes to week 24 were 6.66 for TCZ $4 \mathrm{mg} / \mathrm{kg}$ and 8.83 for TCZ $8 \mathrm{mg} / \mathrm{kg}$ ) [55].

In summary, the results of randomized controlled clinical trials show that TCZ improves health-related activities of daily living and other aspects of QOL, such as the domains of the SF36 and the FACIT Fatigue Scale. Although patient-reported outcome studies are often uncontrolled and subject to problems of selection and outcome bias, they provide important supportive data suggesting that TCZ is associated with improving these outcomes. 


\section{TCZ: RECENT DEVELOPMENTS IN RA}

The recent development of TCZ use in the RA setting includes evidence further characterizing its use as monotherapy and in patients with early RA, as well as the introduction of an SC formulation of TCZ (TCZ-SC). Furthermore, recently published open-label extension (OLE) and observational studies inform the long-term efficacy and safety of TCZ beyond 2 years.

\section{TCZ as Monotherapy}

Two randomized, double-blind, controlled clinical trials assessed TCZ as monotherapy in patients with active RA despite an inadequate response to MTX (ACT-RAY) [56] and, separately, in patients with severe RA who were intolerant to or inappropriate for continued MTX treatment (ADACTA) [49].

The phase 3 ACT-RAY trial demonstrated that there were no clinically relevant differences between adding TCZ $8 \mathrm{mg} / \mathrm{kg}$ to the MTX therapeutic regimen (mean disease duration at baseline 8.2 years) and switching to monotherapy with TCZ $8 \mathrm{mg} / \mathrm{kg}$ (mean disease duration at baseline: 8.3 years) after 24 weeks of therapy when disease activity was measured using the Disease Activity Score based on 28 joints (DAS28) and erythrocyte sedimentation rate (ESR) remission (DAS28-ESR $<2.6 ; 40.4 \%$ in the add-on group vs. $34.8 \%$ in the monotherapy group). There were also no relevant differences in the assessments of radiographic progression of structural damage (Genant-modified Sharp score progression of the smallest detectable change or less: 91 vs. 87\%) [56]. These efficacy measures were maintained at week 52 for both DAS28-ESR-defined remission (45.5 vs. $36.6 \%$ and $p=0.03$ ) and radiographic progression (92.8 vs. $86.1 \%$ of patients) [57].

In the phase 4 ADACTA trial, monotherapy with TCZ $8 \mathrm{mg} / \mathrm{kg}$ (mean disease duration at baseline 7.3 years) was superior to monotherapy with the TNF inhibitor adalimumab $40 \mathrm{mg}$ every 2 weeks (mean disease duration at baseline 6.3 years) in incomplete responders to MTX (inadequate response, contraindication, or intolerance to MTX). Reductions from baseline in the DAS28-ESR were significantly greater with TCZ than adalimumab (-3.3 vs. -1.8 ; $P<0.0001)$.

The FUNCTION trial in MTX-naive patients with early RA (mean disease duration at baseline $0.4-0.5$ years) [51] and the SURPRISE trial in patients with inadequate response to MTX (mean disease duration at baseline 3.6-3.8 years) [58] included TCZ + MTX combination therapy and TCZ monotherapy treatment arms. Although the FUNCTION trial was not powered for comparisons between TCZ combination therapy and TCZ monotherapy, the TCZ $8 \mathrm{mg} / \mathrm{kg}+$ MTX group consistently achieved the best outcomes for all efficacy measures, including DAS28-defined remission [51]. The SURPRISE trial reported higher rates of DAS28defined remission in patients who added TCZ to their MTX treatment regimen compared with those who switched from MTX to TCZ at week 24 (primary end point), but the DAS28-defined remission rates were not significantly different at week 52 or for other efficacy end points, and there was no significant difference in rates of structural remission or clinically relevant radiographic progression (change in the modified total Sharp score [mTSS] $\geq 3$ ) between the add-on and the switch groups. However, among seven add-on and 15 switch patients who did experience clinically relevant radiographic progression, the mean change in total mTSS was greater in the switch group than in the add-on group (9.0 vs. 5.0/year; $P=0.04$ ), suggesting that adding TCZ to MTX monotherapy may lead to superior clinical efficacy and prevent joint destruction compared with switching from MTX to TCZ monotherapy [58].

In summary, in patients with disease duration ranging between 6.7 and 8.3 years, monotherapy with the intravenous formulation of TCZ (TCZ-IV) at $8 \mathrm{mg} / \mathrm{kg}$ seems to be as effective as adding TCZ to MTX monotherapy (combined TCZ + MTX therapy) for incomplete responders to MTX monotherapy. TCZ added to MTX may provide some benefit over TCZ monotherapy in patients with shorter disease duration, but this therapeutic option needs further investigation. 


\section{SC Formulation of TCZ}

Two randomized, double-blind, comparative, phase 3 studies demonstrated the noninferiority of TCZ-SC to TCZ-IV according to standard outcome measures/response rates of the ACR for $20 \%$ improvement (ACR20) at week 24 in patients with RA and an inadequate response to csDMARDS and/or biologic DMARDS (bDMARDs; MUSASHI trial) [59] or to only csDMARDs (SUMMACTA trial) [50]. In addition, similar rates of ACR50 (50\% improvement) and ACR70 (70\% improvement) responses between TCZ-SC and TCZ-IV were reported [50, 59].

An 84-week OLE of the MUSASHI trial demonstrated maintenance of efficacy for DAS28-ESR-defined remission rates between patients continuing TCZ-SC treatment and those switching from TCZ-IV to TCZ-SC [60]. The long-term efficacy and safety of TCZ-SC was also maintained through 97 weeks and found to be comparable to that of TCZ-IV in a 72-week OLE of the SUMMACTA study [54]. TCZ-SC is approved in Japan, the USA (2013), and the EU (2014) for adult patients with RA [37, 45].

The single-arm, open-label, multinational, phase 4 TOZURA trial is currently evaluating the efficacy and safety of 24 weeks of treatment with weekly TCZ-SC $162 \mathrm{mg}$ as either monotherapy or in combination with a csDMARD (at the investigator's discretion) in patients with RA who had an inadequate response to bDMARDs or csDMARDs [61]. An interim analysis of 1246 patients demonstrated equivalent DAS28-ESR and Clinical Disease Activity Index remission rates for both TCZ monotherapy and combination therapy at week 24. These interim results are promising and completed results are anticipated.

In summary, TCZ-SC appears to be as effective as TCZ-IV with comparable safety (discussed below in section Safety, Pharmacokinetics, and Immunogenicity).

\section{TCZ in Early RA}

Two randomized, double-blind, multicenter, phase 3 trials have studied TCZ in MTX-naive patients with early ( $\leq 2$ years) progressive RA
(FUNCTION trial) [51] and in DMARD-naive patients (U-ACT-Early study) [52]. The 2-year U-ACT-Early study demonstrated that more patients treated with TCZ $8 \mathrm{mg} / \mathrm{kg}$ monotherapy and TCZ $8 \mathrm{mg} / \mathrm{kg}+$ MTX combination therapy achieved sustained remission and low disease activity (DAS28-ESR $<2.6$ with swollen joint count $\leq 4$, persisting for $\geq 24$ weeks) than those treated with MTX alone (84 and $86 \%$ vs. $44 \%$, respectively; both $P<0.0001$ ), with no significant differences between TCZ monotherapy versus combined TCZ + MTX therapy [52]. In the FUNCTION trial, patients treated with TCZ $8 \mathrm{mg} / \mathrm{kg}$ monotherapy and TCZ $8 \mathrm{mg} / \mathrm{kg}+$ MTX achieved significantly higher rates of DAS28-ESR-defined remission at week 24 than those treated with MTX monotherapy (44.8 and $38.7 \%$ vs. $15 \%$, respectively; $P<0.0001$ ), with similar clinical efficacy observed between TCZ monotherapy and the combination therapy [51]. The difference in remission rates between these two studies may possibly be ascribed to approximately $20 \%$ of the FUNCTION study population having previously received one or more csDMARD [51], whereas patients enrolled in the U-ACT-Early trial were csDMARD-naive [52].

In summary, in patients with $<2$ years of disease duration, these two studies demonstrate that TCZ $8 \mathrm{mg} / \mathrm{kg}$ monotherapy or combined TCZ $8 \mathrm{mg} / \mathrm{kg}+$ MTX therapy improved DAS28ESR-defined remission rates compared to MTX monotherapy and that adding MTX to TCZ therapy did not improve TCZ response. In 2014, TCZ received approval in the EU for use in early RA (i.e., severe, active, and progressive RA not previously treated with MTX) [45].

\section{Long-Term OLE and Observational Studies}

Although several OLE and observational studies of $<2$ years' duration have been conducted, this section focuses on those with a study duration $>2$ years to provide more clinically relevant findings.

Inhibition of radiographic progression was maintained through 5 years in a 3-year OLE study of the LITHE trial, with less radiographic progression observed for patients originally 
randomly assigned to receive TCZ than for those originally assigned to receive placebo (Genant-modified TSS 1.34 and 3.02, respectively) [62].

The long-term clinical efficacy of TCZ monotherapy in patients with RA who were MTX- or biologic-naive was also assessed in an OLE of the AMBITION trial, which reported sustained improvements in DAS28-ESR-defined remission and ACR response rates through 264 weeks of follow-up in patients remaining on their study medication [63]. A multicenter prospective observational cohort study evaluating clinical responses and radiographic end points for TCZ during 3 years of treatment in Japanese patients with RA reported sustained ( $\geq 6$ months) reductions in DAS28-ESR scores, along with improvements in both clinical (Boolean remission) and structural (Genantmodified TSS) remission rates during 3 years of follow-up [64].

In summary, these studies support the longterm efficacy of TCZ-IV in patients remaining on TCZ treatment, in both clinical trial followup studies and real-world observational cohorts. A long-term decrease in the rate of radiographic progression is also demonstrated.

\section{SAFETY, PHARMACOKINETICS, AND IMMUNOGENICITY}

The safety of TCZ-IV and TCZ-SC has been reported in 11 published phase 3 and 4 trials [40, 42-44, 49-52, 56, 59, 65]. The most common adverse events (AEs) and serious AEs (SAEs) reported in patients with RA treated with TCZ in these trials were infections, such as nasopharyngitis, upper respiratory tract infections, pneumonia, and cellulitis. Other SAEs of interest reported in patients with RA treated with TCZ include gastrointestinal perforations (GIPs), malignancy, myocardial infarction, and stroke. Abnormalities in laboratory test results have also been reported, including elevated liver enzyme levels, decreased neutrophil counts, and changes in lipid levels. Other safety signals were not identified in a cumulative analysis of up to 4.6 years of TCZ exposure based on pooled data from the OPTION,
TOWARD, RADIATE, AMBITION, and LITHE phase 3 trials (with 12,293 patient-years of exposure) compared with the placebo-controlled periods; infections were the most common AEs and SAEs [66]. As of 7 June 2017, the estimated cumulative TCZ exposure in the periodic benefit-risk evaluation report is $>$ 700,000 patient-years (F. Hoffmann-La Roche Ltd., data on file).

A higher incidence of GIPs and specifically lower intestinal perforations (LIPs) has been reported in patients treated with TCZ than in those treated with other biologics or csDMARDs (rates per 1000 patient-years: GIPs, 1.8-2.8 for TCZ vs. 0.6-0.9 for TNF inhibitors [difference: $1.2-1.9 / 1000$ patient-years]; LIPs, 1.26-2.7 for TCZ vs. 0.2-0.76 for TNF inhibitors) [67-69]. For every 1000 patients treated with TCZ per year, between one and two additional GIPs might be expected to occur for patients treated with TCZ compared with those treated with TNF inhibitors [69]. In particular, the risk for LIPs seems to be higher in patients with a history of diverticulitis $[67,68]$, indicating that TCZ should be avoided in patients at risk for GIP. Furthermore, TCZ-treated patients with LIP often exhibit only mild or no symptoms and suppressed C-reactive protein (CRP) levels, which may delay diagnosis [67]. These findings indicate a class effect for anti-IL-6 agents, highlighting the need for careful patient selection (i.e., exclusion of individuals with previous diverticulitis) in clinical trials evaluating TCZ and other anti-IL- 6 agents in order to reduce the risk for LIP.

Neutropenia and malignancy are two additional safety issues of interest for patients receiving TCZ. In a retrospective cohort study of patients with rheumatic diseases, TCZ was associated with a higher incidence of neutropenia compared with abatacept and infliximab $(18.6 \%$ vs. $3.8 \%$ and $2.8 \%$, respectively; $P<0.001)$. This increased incidence of neutropenia did not result in a higher risk for severe infections [70]. Despite concerns for the risk for malignancy during immunosuppressive therapy in patients with RA, an analysis of phase 3 trials and long-term extension studies did not demonstrate increased risk for overall or sitespecific malignancies above the risk expected in 
Table 1 Summary of the pharmacokinetics profiles for the intravenous and subcutaneous formulations of tocilizumab in patients with rheumatoid arthritis, systemic juvenile idiopathic arthritis (JIA), and polyarticular JIA [37, 72, 73]

\begin{tabular}{|c|c|c|c|c|c|c|c|}
\hline \multirow[t]{3}{*}{ PK parameter } & \multicolumn{4}{|c|}{ Rheumatoid arthritis } & \multirow{3}{*}{$\begin{array}{l}\text { sJIA } \\
\text { TCZ-IV } \\
8 \mathrm{mg} / \mathrm{kg} \\
(B W \geq 30 \mathrm{~kg}) \text { or } \\
12 \mathrm{mg} / \mathrm{kg} \\
(B W<30 \mathrm{~kg}) \text { every } \\
2 \text { weeks }\end{array}$} & \multirow{2}{*}{\multicolumn{2}{|c|}{$\frac{\text { pJIA }}{\text { TCZ-IV }}$}} \\
\hline & \multicolumn{2}{|l|}{ TCZ-IV } & \multicolumn{2}{|l|}{ TCZ-SC } & & & \\
\hline & $\begin{array}{l}4 \mathrm{mg} / \mathrm{kg} \\
\text { every } 4 \\
\text { weeks }\end{array}$ & $\begin{array}{l}8 \mathrm{mg} / \mathrm{kg} \\
\text { every } 4 \\
\text { weeks }\end{array}$ & $\begin{array}{l}162 \mathrm{mg} \\
\text { every } \\
\text { weeks }\end{array}$ & $\begin{array}{l}162 \mathrm{mg} \\
\text { every } \\
\text { other } \\
\text { weeks }\end{array}$ & & $\begin{array}{l}8 \mathrm{mg} / \mathrm{kg} \\
(\mathrm{BW} \geq 30 \mathrm{~kg}) \\
\text { every } 4 \text { weeks }\end{array}$ & $\begin{array}{l}10 \mathrm{mg} / \mathrm{kg} \\
(\mathrm{BW}<30 \mathrm{~kg}) \\
\text { every } 4 \text { weeks }\end{array}$ \\
\hline $\begin{array}{l}\text { Estimated mean } \\
\text { steady state } \\
\text { AUC (SD), } \\
\mu \mathrm{g} / \mathrm{h} / \mathrm{mL}\end{array}$ & $\begin{array}{l}13,000 \\
\quad(5800)\end{array}$ & $\begin{array}{l}35,000 \\
\quad(15,500)\end{array}$ & $\begin{array}{l}8200 \\
\quad(3600)\end{array}$ & $\begin{array}{l}3200 \\
\quad(2700)\end{array}$ & $32,200(9960)$ & $29,500(8660)$ & $23,200(6100)$ \\
\hline $\begin{array}{l}\text { Estimated mean } \\
\text { steady state } \\
C_{\min }(\mathrm{SD}) \text {, } \\
\mu \mathrm{g} / \mathrm{mL}\end{array}$ & $\begin{array}{l}1.49 \\
(2.13)\end{array}$ & $\begin{array}{l}9.74 \\
\quad(10.5)\end{array}$ & $\begin{array}{l}44.6 \\
(20.6)\end{array}$ & $5.6(7.0)$ & $57.5(23.3)$ & $7.49(8.2)$ & $2.35(3.59)$ \\
\hline $\begin{array}{l}\text { Estimated mean } \\
\text { steady state } \\
C_{\max }(\mathrm{SD}) \\
\mu \mathrm{g} / \mathrm{mL}\end{array}$ & $\begin{array}{l}88.3 \\
\quad(41.4)\end{array}$ & $183(85.6)$ & $\begin{array}{l}50.9 \\
\quad(21.8)\end{array}$ & $\begin{array}{l}12.3 \\
(8.7)\end{array}$ & $245(57.2)$ & $182(37)$ & $175(32)$ \\
\hline$t_{1 / 2}$ (days) & $\sim 11$ & $\sim 13$ & $\sim 13$ & $\sim 5$ & NA & NA & NA \\
\hline Volume of distril & ution $(\mathrm{L})$ & & & & & & \\
\hline Central & 3.5 & & 4.5 & & NA & NA & NA \\
\hline Peripheral & 2.9 & & 2.8 & & NA & NA & NA \\
\hline $\begin{array}{l}\text { Bioavailability } \\
\text { (\%) }\end{array}$ & NA & NA & 79.5 & & NA & NA & NA \\
\hline $\begin{array}{r}\text { Clearance } \\
\text { (L/day) }\end{array}$ & 0.3 & & 0.216 & & NA & NA & NA \\
\hline
\end{tabular}

$A U C$ Area under the concentration curve, $B W$ body weight, $C_{\max }$ maximum concentration, $C_{\min }$ minimum concentration, $I V$ intravenous, $N A$ not available, $p J I A$ polyarticular juvenile idiopathic arthritis, $P K$ pharmacokinetics, $S C$ subcutaneous, $S D$ standard deviation, $s I I A$ systemic juvenile idiopathic arthritis, $t_{1 / 2}$ half-life, $T C Z$ tocilizumab

patients with RA [71]. However, patients treated with TCZ should be monitored for malignancies to provide data that can be used for to assess risk over the longer term.

The data for the pharmacokinetics (PK) of TCZ-IV and TCZ-SC are based on population PK analyses of 1793 and 1759 patients with RA, respectively [72-74]. In addition, population PK analyses of 75 patients with sJIA and 188 patients with pJIA have been conducted to determine the PK of TCZ-IV in these patients (F. Hoffmann-La Roche Ltd., data on file). We have summarized the PK profiles in Table 1 $[37,72,73]$. PK exposure parameters for TCZ were found to be similar between healthy individuals and patients with RA, indicating that even the presence of active disease does not impact the PK profile of TCZ [74]. The PK profile 
of TCZ is not affected by alcohol, age, or ethnicity. In addition, no clinically relevant additive effects on the PK profiles of TCZ and MTX were observed when they were administered together in patients with RA [72, 75]. This result was also supported by the FUNCTION trial, which reported similar serum TCZ levels in patients receiving or not receiving MTX in combination with TCZ [51].

Clinical experience with both TCZ-IV and TCZ-SC has demonstrated low immunogenicity in several indications, including RA [76], Castleman's disease [16], and JIA [28, 29, 31]. In a pooled analysis of data from 13 phase 3 clinical trials (8 TCZ-IV, 5 TCZ-SC) and one TCZ-IV safety study, antidrug antibodies were identified in 47 of $3094(1.5 \%)$ and 69 of $5806(1.2 \%)$ patients treated with TCZ-SC and TCZ-IV, respectively [76]; neutralizing antidrug antibodies were confirmed in 40 of 3094 (1.3\%) and 54 of $5806(0.9 \%)$ of these patients, respectively [76].

In summary, the safety, $\mathrm{PK}$, and immunogenicity of TCZ-SC appear to be similar to those for TCZ-IV.

\section{THE ROLE OF TCZ IN CURRENT TREATMENT REGIMENS FOR RA}

Tocilizumab has been incorporated as a treatment option into current ACR and EULAR recommendations for the management of RA [77, 78]. ACR 2015 guidelines recommend that a non-TNF biologic (rituximab or TCZ), with or without MTX, can be considered if disease activity remains moderate or high despite the use of csDMARDs or after failure of TNF inhibitor treatment [77]. EULAR 2016 updated guidelines recommend TCZ as a bDMARD option [78]. A treatment target of sustained remission or low disease activity is recommended in the guidelines for every patient, with the goal of achieving sustained remission. For patients who do not improve or reach their target end point after receiving csDMARDs for 3-6 months, a bDMARD or a targeted synthetic DMARD (tsDMARD), such as tofacitinib or baricitinib, should be added to the treatment regimen. The guidelines state that bDMARDs should usually be initiated in combination with a csDMARD except in patients who cannot use them as comedication, in which case IL-6 pathway inhibitors and tsDMARDs may offer some advantages over other bDMARDs.

In summary, updated guidelines regarding csDMARDs, bDMARDs, and tsDMARDs include the use of non-TNF-inhibitor biologics, such as TCZ (abatacept or rituximab) and place these drugs in the RA armamentarium. However, the specific position of TCZ in the treatment algorithm is yet to be determined.

\section{TCZ: PROMISING RESEARCH, INCLUDING POTENTIAL INDICATIONS}

\section{Systemic Sclerosis}

Given that IL-6 is involved in both innate and adaptive immune responses, inhibition of IL-6mediated signaling with TCZ may be an effective therapeutic approach for the treatment of SSc. Initial clinical experience with TCZ in SSc includes softening of the skin and histological thinning of the collagen fiber bundles in the dermis of two patients with SSc [79], while a small observational study of patients with SSc and refractory polyarthritis reported the achievement of a good EULAR response in 10 of 15 patients [80]. In the recent double-blind phase 2 faSScinate trial, there was encouraging (although not statistically significant) numerical improvement in skin thickening and evidence of less decline in lung function in adult patients with progressive SSc treated with TCZSC compared to those receiving placebo [81]. Further studies are needed, and an ongoing 2-year randomized phase 3 trial of TCZ-SC $162 \mathrm{mg}$ in SSc is under way (ClinicalTrials.gov identifier NCT02453256).

\section{Steroid Sparing in RA}

A trial assessing the steroid-sparing ability of TCZ (SEMIRA trial; ClinicalTrials.gov identifier NCT02573012) is currently in progress. The aim of this study is to evaluate the efficacy of 
maintenance treatment with TCZ-SC or TCZ-IV with or without stable doses of csDMARD in patients with RA who have DAS-defined low disease activity $(\leq 3.2)$ for $\geq 4$ weeks before randomization and have been receiving glucocorticoids $(5-15 \mathrm{mg} /$ day of prednisone or equivalent) for $\geq 20$ weeks before screening. Eligible patients were randomly assigned to receive either a blinded 24-week prednisone tapering regimen or a blinded continuation of prednisone $5 \mathrm{mg} /$ day for 24 weeks. Patient recruitment for the SEMIRA trial is now completed and the results are pending.

\section{Other Diseases}

Given the far-reaching involvement of IL-6mediated signaling in inflammatory disorders, TCZ is being investigated in a number of other diseases.

The TENOR trial was a prospective, open-label, longitudinal, multicenter study evaluating TCZ therapy in patients with polymyalgia rheumatica (PMR); significant reductions in ${ }^{18} \mathrm{~F}$ fluorodeoxyglucose $\left({ }^{18} \mathrm{~F}\right.$-FDG) uptake (assessed by positron emission tomography-computed tomography) following TCZ therapy suggested a decrease in disease activity [82]. Additionally, the randomized, double-blind, placebo-controlled, phase 3 SEMAPHORE trial is recruiting patients and will evaluate the safety and efficacy of TCZ in patients with PMR who are glucocorticoid dependent (ClinicalTrials.gov identifier NCT02908217).

A small multicenter study of 11 patients with uveitis associated with Behçet's disease reported improvements in visual acuity, number of blood cells in the anterior chamber of the eye, vitritis, retinal vasculitis, optical coherence tomography, achievement of complete remission, and prednisone dose reduction in patients receiving TCZ therapy [83]. Early-phase trials are under way to evaluate both TCZ-IV (ClinicalTrials.gov identifier NCT01717170) and TCZSC (ClinicalTrials.gov identifier NCT02929251) in patients with noninfectious uveitis.

No published prospective clinical trials evaluating TCZ in AOSD are available, but promising efficacy results have been observed in several case reports and retrospective analyses [84-87]. Improvements in clinical (fever, rash, and myalgia) and laboratory (ESR and CRP) manifestations were observed after treatment with TCZ in a review of 24 cases of AOSD in Korean patients [88]. A multicenter study of 75 patients with AOSD treated with TCZ or anakinra also reported similar improvements in clinical manifestations (fever, articular, rash, and lymphadenopathy) over 12 months of therapy between the two study treatments, although improvements in CRP and ESR levels appeared to be greater with TCZ than with anakinra [89]. Furthermore, the preliminary results of a small, prospective, single-arm pilot study in eight patients recently reported no significant AEs with TCZ monotherapy and improvement rates of $100 \%$ for fever, $75.0 \%$ for arthralgia, and $71.4 \%$ for eruption at 6 months in patients with AOSD [90].

Evidence from case reports, small studies, and retrospective studies suggest that TCZ may be an effective therapeutic option in vasculitis syndromes other than GCA, including systemic rheumatoid vasculitis, PMR, Takayasu arteritis, and Behçet's disease [91-96]. TCZ has also shown promise in several other indications, including amyloidosis [97-100], FMF [101-103], Schnitzler's syndrome [104, 105], and polychondritis [106-109]. Results of the doubleblind, randomized, placebo-controlled, phase 3 TAKT trial in 36 patients with Takayasu arteritis demonstrated a trend toward relapse suppression in favor of TCZ-SC over placebo [110]. However, the primary end point (time to first protocol-defined relapse) was not met in the intent-to-treat population (hazard ratio $=0.41$; 95.41\% CI $0.15-1.10 ; \quad P=0.0596)$. TCZ-SC showed numerically favorable (though not statistically significant) trends for improvement in objective systemic symptoms, subjective systemic symptoms, elevated inflammation marker levels, vascular lesions, and ischemic symptoms accompanied by organ lesions in the TAKT trial [110]. TCZ was approved in August 2017 for the treatment of Takayasu arteritis in Japan based on the results of the TAKT study.

Clinical studies evaluating TCZ in patients with ankylosing spondylitis have been conducted, but they failed to demonstrate efficacy 
$[111,112]$. Ongoing trials are under way to assess TCZ in a range of disorders, such as hand osteoarthritis, new-onset type 1 diabetes, diabetic macular edema, myocardial infarction, pulmonary arterial hypertension, psychiatric disorders (e.g., schizophrenia, schizoaffective disorder, and major depressive disorder), primary Sjögren's syndrome, hepatocellular carcinoma, chronic lymphocytic leukemia, refractory dermatomyositis and polymyositis, amyotrophic lateral sclerosis, graft-versus-host disease, and human immunodeficiency virus (HIV) infection.

In summary, case reports and observational or retrospective studies indicate that further studies of TCZ may be appropriate for AOSD, Behçet's disease, other vasculitides, FMF, and polychondritis. IL-6 is a pleotropic cytokine with multiple effects and its inhibition is leading to a large variety of clinical trials in multiple diseases. Results from these trials will likely guide further studies into other indications.

\section{OTHER IL-6-TARGETED BIOLOGICS}

Novel biologics that target IL-6 signaling are undergoing clinical development in the RA setting, including human anti-IL-6R alpha (sarilumab, approved in the USA on 22 May 2017 for the treatment of RA) and anti-IL- 6 cytokine (olokizumab, sirukumab, and clazakizumab) monoclonal antibodies. Interestingly, blockade of the IL-6R (e.g., with TCZ or sarilumab) may be associated with distinct clinical effects from blockade of the IL-6 cytokine (e.g., with sirukumab or clazakizumab). Use of a human primary cell-based phenotypic screening system (BioMAP®; DiscoverX, Fremont, CA, USA; now part of Eurofins Scientific, Brussels, Belgium) demonstrated that sirukumab and TCZ had BioMAP phenotypic signatures that were distinct from each other, suggesting that the impact of TCZ on IL-6R signaling is distinct from that of sirukumab [113]. Nevertheless, preliminary evidence to date indicates that these novel IL-6-targeted biologics show promise with regard to their long-term efficacy and safety.

\section{Sarilumab}

Sarilumab has been approved in the USA and EU for the treatment of patients with RA who have an inadequate response to MTX or csDMARDs. This approval was based on the positive findings of two pivotal phase 3 clinical trials, MOBILITY and TARGET, in which a total of 1164 patients were exposed to sarilumab.

Sarilumab was investigated in MOBILITY, a phase 3 trial of patients with RA who had inadequate response to MTX [114]. Therapy with sarilumab 150 or $200 \mathrm{mg}$ every 2 weeks in combination with MTX was associated with significant improvements compared with placebo + MTX, according to ACR20 response rates at week 52 (58.0 and $66.4 \%$ vs. $33.4 \%$ ), changes from baseline to week 16 in HAQ-DI physical function scores $(-0.53$ and -0.55 vs. -0.29$)$, and the change from baseline to week 52 in the Sharp/van der Heijde radiographic scores (0.90 and 0.25 vs. 2.78 ) (all $P<0.0001$ ). An OLE study (EXTEND; ClinicalTrials.gov identifier NCT01146652) of the MOBILITY trial also demonstrated that sarilumab $200 \mathrm{mg}$ provided durable clinical response and stabilization of radiographic progression at 3 years [115]. Furthermore, most patients who reduced their dosage of sarilumab from 200 to $150 \mathrm{mg}$ every 2 weeks in the OLE study demonstrated sustained efficacy with regard to ACR20 response rate $(83.1 \%)$ and improvements in HAQ-DI scores $(-0.68)$, along with continued improvements in abnormalities in laboratory test results, signs and symptoms of RA, and physical function [116].

The randomized, double-blind, head-tohead, phase $3 \mathrm{MONARCH}$ trial demonstrated that sarilumab $200 \mathrm{mg}$ was superior to adalimumab with regard to the change from baseline in DAS28-ESR $(-3.28$ vs. $-2.20 ; P<0.0001)$ in patients with RA and inadequate response to MTX [117].

Results of the randomized phase 3 TARGET trial (ClinicalTrials.gov identifier NCT01709578), which evaluated sarilumab + csDMARD therapy in patients with RA who were inadequate responders to or intolerant of TNF inhibitors, demonstrated that sarilumab $150 \mathrm{mg}$ and $200 \mathrm{mg}$ every 2 weeks were 
associated with significant improvements in ACR20 response rates at week 24 (56 and 61\% vs. $34 \%$; both $P<0.0001$ ) and HAQ-DI physical function scores at week $12(-0.50$ and -0.49 vs. -0.29 ; both $P<0.001$ ), compared to placebo [118]. Analyses of the TARGET trial data also showed significant and clinically meaningful improvements from baseline in patientreported outcomes (fatigue, morning stiffness, pain, and work productivity) and significant reductions in levels of biomarkers of bone resorption and joint damage with sarilumab $[119,120]$. Complete published results of these analyses are pending. Published results are also pending for the randomized phase 3 ASCERTAIN trial (ClinicalTrials.gov identifier NCT01768572), which evaluated SC sarilumab $150 \mathrm{mg}$ or $200 \mathrm{mg}$ every 2 weeks and TCZ-IV $4 \mathrm{mg} / \mathrm{kg}$ increased to $8 \mathrm{mg} / \mathrm{kg}$ based on clinical response in patients receiving background csDMARDs who had an inadequate response to or were intolerant of TNF inhibitors. Preliminary results do not show clinically meaningful differences between sarilumab $150 \mathrm{mg}$ or $200 \mathrm{mg}$ and TCZ with regard to treatmentemergent AEs $(67,71$, and 67\%, respectively), SAEs $(2,6$, and $7 \%$, respectively), or serious infections $(0,2$, and $2 \%$, respectively) [121].

\section{Olokizumab}

Olokizumab was evaluated in a phase $2 \mathrm{~b}$ trial in 221 patients with RA who had an inadequate response to TNF inhibitor therapy. DAS28-CRPdefined improvements from baseline to week 12 for olokizumab versus placebo $(-1.16$ to -2.68 vs. -0.19 to -0.78 ; all $P<0.05)$ were reported, as were improvements in ACR20 response rates (32.5-73.8\% vs. $17.1-29.9 \%)$ [122, 123]. A second phase 2 study in 119 patients with RA reported greater improvements in all olokizumab treatment arms versus placebo for DAS28-CRP-defined improvements from baseline (all $P<0.0001$ ) and ACR20 rates (all $P<0.05)$ at week 12 [123]. OLE studies of these phase 2 trials demonstrated that olokizumab was generally well tolerated and associated with sustained reductions from baseline in disease activity (DAS28-CRP) through 48 weeks (olokizumab: -0.60 to -0.68 ; placebo: -1.70 to -1.76$)$ [124]. A pooled analysis of these phase 2 trials and their OLE studies indicated that both Western and Asian patients receiving olokizumab had greater improvements in patient-reported outcomes compared with placebo-treated patients at week 12; these improvements were sustained through 40 and 48 weeks during the OLE studies. For example, changes from baseline in HAQ-DI scores at weeks 12 and 48 were consistently greater with olokizumab than with placebo in 198 Western patients $(-0.32$ and -0.45 vs. -0.07 and $-0.15)$ and in 105 Asian patients $(-0.41$ and -0.60 vs. 0 and -0.28 ) patients [125].

\section{Sirukumab}

A phase 2 trial of sirukumab reported significant improvements in ACR50 response rates at week 24 for sirukumab $100 \mathrm{mg}$ every 2 weeks $(n=17)$ versus placebo $(n=19)(26.7$ vs. $3.3 \% ; P<0.05)$ and DAS28-CRP-defined improvements from baseline for all sirukumab dose groups versus placebo $(2.0-2.2$ vs. 1.0 ; all $P<0.001)$ in patients with RA and inadequate response to MTX [126].

The global, randomized, double-blind, phase 3 SIRROUND-H trial demonstrated significantly greater DAS28-ESR-defined improvements from baseline at week 24 with sirukumab $100 \mathrm{mg}$ every 2 weeks $(n=187)$ and sirukumab $50 \mathrm{mg}$ every 4 weeks $(n=186)$ versus adalimumab every 2 weeks $(n=186)(-2.96$ and -2.58 vs. $-2.19 ; P<0.001$ and $P=0.013$, respectively) in biologic-naive patients with RA who were intolerant of or inadequate responders to MTX. However, the second co-primary end point (ACR50 at week 24) was not met (35.3 and $26.9 \%$ vs. $31.7 \% ; P=0.464$ and $P=0.306$, respectively). Rates of SAEs were $2.7 \%$ for sirukumab $100 \mathrm{mg}, 7.0 \%$ for sirukumab $50 \mathrm{mg}$, and $4.3 \%$ for adalimumab [127].

Although substantial evidence of efficacy is available for sirukumab in the RA setting, the U.S. FDA rejected its regulatory approval in September 2017 based on safety concerns over serious infections, malignancy, major adverse cardiac events, and abnormalities in laboratory 
tests, including a decreased neutrophil count. A trend of increased overall mortality for sirukumab over placebo was reported, which was mainly associated with major adverse cardiac events, infection, and malignancy [128].

\section{Clazakizumab}

Clazakizumab with or without MTX was evaluated in a phase $2 \mathrm{~b}$ trial in 418 patients with RA and an inadequate response to MTX. Significant improvements in ACR20 response rates were observed for monotherapy with clazakizumab 100 and $200 \mathrm{mg}$ and for combined clazakizumab 25, 100, and $200 \mathrm{mg}+$ MTX therapy compared to MTX monotherapy $(55.0,61.0$, $76.3,73.3$, and $60.0 \%$ vs. $39.3 \%$; all $P<0.05$ ) [129].

\section{Vobarilizumab}

The anti-IL-6R nanobody vobarilizumab (ALX0061) is currently being evaluated as monotherapy (150 mg every 4 weeks, $150 \mathrm{mg}$ every 2 weeks, or $225 \mathrm{mg}$ every 2 weeks) in a randomized, head-to-head, phase $2 \mathrm{~b}$ trial versus TCZ in patients with moderate to severe RA who were intolerant to MTX or for whom continued MTX treatment is inappropriate [130]. At week 12, ACR20 response rates were similar between the three vobarilizumab dose groups and TCZ (73-81 vs. 78\%), although DAS28-ESR-defined remission rates appeared to be higher with the vobarilizumab $150 \mathrm{mg}$ every 4 weeks and $225 \mathrm{mg}$ every 2 weeks dosage groups versus TCZ (34 and 40\% vs. 25\%) [130].

In summary, two anti-IL-6R biologics have been approved for the treatment of RA, namely, TCZ and sarilumab, and multiple agents blocking the IL-6 signaling pathway are in development in this constantly changing field. Available data to date suggest that the newer agents may have similarities to TCZ; however, this inference is based mainly on data presented in abstract format, and it would therefore be premature and potentially misleading to compare efficacy and safety among these IL-6-targeted therapies. More data on the newer agents are eagerly awaited to inform physicians on the treatment of patients with RA and other diseases.

\section{CONCLUSIONS}

Tocilizumab is the first-in-class humanized antiIL-6R $\alpha$ monoclonal antibody to undergo global clinical development, resulting in its approval for the management of RA, Castleman's disease, sJIA, pJIA, and GCA. In the RA setting, approval of TCZ was based on data from five pivotal phase 3 clinical trials that demonstrated its efficacy and safety in a range of patient populations, including inadequate responders to MTX and inadequate responders to TNF inhibitors. This review emphasizes recent developments with TCZ and other IL-6-targeted biologics; TCZ monotherapy has been evaluated, including in the early RA setting, and an SC formulation of TCZ was developed. Longterm safety studies have been encouraging, with no new toxicities identified and no difference in the frequencies of AEs and SAEs observed compared with those reported in pre-approval studies. Results reported to date suggest that TCZ has low immunogenicity.

TCZ has recently been approved for the treatment of GCA and is also being investigated for the treatment of SSc. However, TCZ was found not to be effective for the treatment of ankylosing spondylitis. Other off-label indications in which TCZ is being evaluated include RA-associated vasculitis, Takayasu arteritis, AOSD, PMR, Behçet's disease, amyloidosis, FMF, Schnitzler's syndrome, and polychondritis. However, limited data have been published for these diseases, and future prospective studies may determine whether there is a role for TCZ in the treatment of these diseases. Another IL- 6 therapy, sarilumab, has been recently approved for the treatment of patients with RA who are inadequate responders to MTX/csDMARD, with comparable results to adalimumab. However, long-term data are still needed for this drug.

Novel IL-6 signaling-targeted biologics being developed have shown promise in the RA setting. However, the current lack of published data in the literature for these agents precludes accurate comparisons to data for TCZ. Well- 
designed clinical trials are needed to establish the efficacy and safety profiles of these newer agents; in particular, direct comparator studies to TCZ are needed.

\section{ACKNOWLEDGEMENTS}

Funding. No funding was received for article processing charges. Support for medical writing assistance was provided by F. Hoffmann-La Roche Ltd.

Authorship. All named authors meet the International Committee of Medical Journal Editors (ICMJE) criteria for authorship for this manuscript, take responsibility for the integrity of the work as a whole and have given final approval for the version to be published.

Medical Writing, Editorial, and Other Assistance. Editorial assistance in the preparation of this manuscript was provided by Maxwell Chang and Sara Duggan, Ph.D., of ApotheCom (Yardley, PA, USA). Support for this assistance was funded by F. Hoffmann-La Roche, Basel, Switzerland.

Disclosures. Andrea Rubbert-Roth reports honoraria and advisory board fees from Roche and honoraria from Chugai during the conduct of the submitted work as well as honoraria and advisory board fees from Sanofi, Bristol-Myers Squibb, Pfizer, MSD, and Eli Lilly, and honoraria from UCB and AbbVie outside of the submitted work. Daniel E. Furst reports grant/research support from AbbVie, Actelion, Amgen, BristolMyers Squibb, Corbus, National Institutes of Health, Novartis, Pfizer, and Roche/Genentech and is a consultant for AbbVie, Actelion, Amgen, Bristol-Myers Squibb, Cytori, Novartis, Pfizer, and Roche/Genentech outside of the submitted work. J. Michael Nebesky is an employee of and reports personal fees from $\mathrm{F}$ Hoffmann-La Roche Ltd during the conduct of the work and outside of the submitted work. Angela Jin is an employee of Genentech Inc. Erhan Berber is an employee of and owns stock and stock options in Genentech Inc.
Compliance with Ethics Guidelines. This article is based on previously conducted studies and does not involve any new studies of human or animal subjects performed by any of the authors.

Open Access. This article is distributed under the terms of the Creative Commons Attribution-NonCommercial 4.0 International License (http://creativecommons.org/licenses/ by-nc/4.0/), which permits any noncommercial use, distribution, and reproduction in any medium, provided you give appropriate credit to the original author(s) and the source, provide a link to the Creative Commons license, and indicate if changes were made.

\section{REFERENCES}

1. Tanaka T, Narazaki M, Kishimoto T. IL-6 in inflammation, immunity, and disease. Cold Spring Harb Perspect Biol. 2014;6:a016295.

2. Madhok R, Crilly A, Watson J, Capell HA. Serum interleukin 6 levels in rheumatoid arthritis: correlations with clinical and laboratory indices of disease activity. Ann Rheum Dis. 1993;52:232-4.

3. Lepore L, Pennesi M, Saletta S, Perticarari S, Presani G, Prodan M. Study of IL-2, IL-6, TNF alpha, IFN gamma and beta in the serum and synovial fluid of patients with juvenile chronic arthritis. Clin Exp Rheumatol. 1994;12:561-5.

4. Spirchez M, Samasca G, Iancu M, Bolba C, Miu N. Relation of interleukin-6, TNF-alpha and interleukin-1alpha with disease activity and severity in juvenile idiopathic arthritis patients. Clin Lab. 2012;58:253-60.

5. Yoshizaki K, Matsuda T, Nishimoto N, et al. Pathogenic significance of interleukin-6 (IL-6/BSF-2) in Castleman's disease. Blood. 1989;74:1360-7.

6. Song SN, Tomosugi N, Kawabata H, Ishikawa $\mathrm{T}$, Nishikawa T, Yoshizaki K. Down-regulation of hepcidin resulting from long-term treatment with an anti-IL-6 receptor antibody (tocilizumab) improves anemia of inflammation in multicentric Castleman disease. Blood. 2010;116:3627-34.

7. Barnes TC, Anderson ME, Moots RJ. The many faces of interleukin-6: the role of IL-6 in inflammation, vasculopathy, and fibrosis in systemic sclerosis. Int J Rheumatol. 2011;2011:721608. 
8. Roche NE, Fulbright JW, Wagner AD, Hunder GG, Goronzy JJ, Weyand CM. Correlation of interleukin-6 production and disease activity in polymyalgia rheumatica and giant cell arteritis. Arthritis Rheum. 1993;36:1286-944.

9. Weyand CM, Goronzy JJ. Immune mechanisms in medium and large-vessel vasculitis. Nat Rev Rheumatol. 2013;9:731-40.

10. Mavragani CP, Spyridakis EG, Koutsilieris M. Adultonset Still's disease: from pathophysiology to targeted therapies. Int J Inflamm. 2012;2012:8790200.

11. Baykal Y, Saglam K, Yilmaz MI, Taslipinar A, Akinci SB, Inal A. Serum sIL-2r, IL-6, IL-10 and TNF-alpha level in familial Mediterranean fever patients. Clin Rheumatol. 2003;22:99-101.

12. Oktem S, Yavuzsen TU, Sengul B, Akhunlar H, Akar S, Tunca M. Levels of interleukin-6 (IL-6) and its soluble receptor (sIL-6R) in familial Mediterranean fever (FMF) patients and their first degree relatives. Clin Exp Rheumatol. 2004;22:S34-6.

13. de Koning HD, Schalkwijk J, Stoffels M, et al. The role of interleukin-1 beta in the pathophysiology of Schnitzler's syndrome. Arthritis Res Ther. 2015;17:187.

14. Launay D, Dutoit-Lefevre V, Faure E, et al. Effect of in vitro and in vivo anakinra on cytokines production in Schnitzler syndrome. PLoS One. 2013;8:e593277.

15. Stabler T, Piette JC, Chevalier X, Marini-Portugal A, Kraus VB. Serum cytokine profiles in relapsing polychondritis suggest monocyte/macrophage activation. Arthritis Rheum. 2004;50:3663-7.

16. Nishimoto N, Kanakura Y, Aozasa K, et al. Humanized anti-interleukin- 6 receptor antibody treatment of multicentric Castleman disease. Blood. 2005;106:2627-32.

17. Nishimoto N, Kishimoto T. Humanized antihuman IL-6 receptor antibody, tocilizumab. Handb Exp Pharmacol. 2008;(181)151-60.

18. Sebba A. Tocilizumab: the first interleukin-6-receptor inhibitor. Am J Health Syst Pharm. 2008;65:1413-8.

19. Tanaka T, Narazaki M, Ogata A, Kishimoto T. A new era for the treatment of inflammatory autoimmune diseases by interleukin- 6 blockade strategy. Semin Immunol. 2014;26:88-96.

20. Uchiyama Y, Yorozu K, Hashizume M, Moriya Y, Mihara M. Tocilizumab, a humanized anti-interleukin-6 receptor antibody, ameliorates joint swelling in established monkey collagen-induced arthritis. Biol Pharm Bull. 2008;31:1159-63.

21. Richez C, Barnetche T, Khoryati L, et al. Tocilizumab treatment decreases circulating myeloid dendritic cells and monocytes, 2 components of the myeloid lineage. J Respir Dis. 2012;39:1192-7.

22. Kasama $T$, Isojima $S$, Umemura $M$, et al. Serum macrophage migration inhibitory factor levels are correlated with response to tocilizumab therapy in patients with rheumatoid arthritis. Rheumatol Int. 2014;34:429-33.

23. Samson M, Audia S, Janikashvili N, et al. Brief report: inhibition of interleukin- 6 function corrects Th17/Treg cell imbalance in patients with rheumatoid arthritis. Arthritis Rheum. 2012;64:2499-503.

24. Pesce B, Soto L, Sabugo F, et al. Effect of interleukin6 receptor blockade on the balance between regulatory $\mathrm{T}$ cells and $\mathrm{T}$ helper type 17 cells in rheumatoid arthritis patients. Clin Exp Immunol. 2013;171:237-42.

25. Stubenrauch K, Wessels U, Birnboeck H, Ramirez F, Jahreis A, Schleypen J. Subset analysis of patients experiencing clinical events of a potentially immunogenic nature in the pivotal clinical trials of tocilizumab for rheumatoid arthritis: evaluation of an antidrug antibody ELISA using clinical adverse event-driven immunogenicity testing. Clin Ther. 2010;32:1597-609.

26. Roll P, Muhammad K, Schumann $\mathrm{M}$, et al. In vivo effects of the anti-interleukin- 6 receptor inhibitor tocilizumab on the B cell compartment. Arthritis Rheum. 2011;63:1255-64.

27. Snir A, Kessel A, Haj T, Rosner I, Slobodin G, Toubi E. Anti-IL-6 receptor antibody (tocilizumab): a B cell targeting therapy. Clin Exp Rheumatol. 2011;29:697-700.

28. Yokota S, Imagawa T, Mori M, et al. Efficacy and safety of tocilizumab in patients with systemic-onset juvenile idiopathic arthritis: a randomised, double-blind, placebo-controlled, withdrawal phase III trial. Lancet. 2008;371:998-1006.

29. Imagawa T, Yokota S, Mori M, et al. Safety and efficacy of tocilizumab, an anti-IL-6-receptor monoclonal antibody, in patients with polyarticularcourse juvenile idiopathic arthritis. Mod Rheumatol. 2012;22:109-15.

30. de Benedetti F, Brunner HI, Ruperto N, et al. Tocilizumab in systemic juvenile idiopathic arthritis. N Engl J Med. 2012;367:2385-95.

31. Brunner HI, Ruperto N, Zuber Z, et al. Efficacy and safety of tocilizumab in patients with polyarticular- 
course juvenile idiopathic arthritis: results from a phase 3, randomised, double-blind withdrawal trial. Ann Rheum Dis. 2014;74:1110-7.

32. Weyand CM, Goronzy JJ. Clinical practice: giantcell arteritis and polymyalgia rheumatica. N Engl J Med. 2014;371:50-7.

33. Deng J, Younge BR, Olshen RA, Goronzy JJ, Weyand CM. Th17 and Th1 T-cell responses in giant cell arteritis. Circulation. 2010;121:906-15.

34. Villiger PM, Adler S, Kuchen S, et al. Tocilizumab for induction and maintenance of remission in giant cell arteritis: a phase 2, randomised, double-blind, placebo-controlled trial. Lancet. 2016;387:1921-7.

35. Stone JH, Tuckwell K, Dimonaco S, et al. Trial of tocilizumab in giant-cell arteritis. N Engl J Med. 2017;377:317-28.

36. Stone JH, Tuckwell K, Dimonaco S, et al. Optimal dose of tocilizumab for the treatment of giant cell arteritis: efficacy, safety, and exposure-efficacy analysis from GiACTA. Ann Rheum Dis. 2017;76[Suppl 2]:107.

37. Genentech Inc. Actemra ${ }^{\circledR}$ (tocilizumab) injection for intravenous infusion. South San Francisco: Genentech, Inc.; 2017.

38. Grupp SA, Laetsch TW, Buechner J, et al. Analysis of a global registration trial of the efficacy and safety of CTL019 in pediatric and young adults with relapsed/refractory acute lymphoblastic leukemia (ALL). Blood. 2016;128 (abstract 221).

39. Navarro-Millan I, Singh JA, Curtis JR. Systematic review of tocilizumab for rheumatoid arthritis: a new biologic agent targeting the interleukin-6 receptor. Clin Ther. 2012;34:788-802.

40. Jones G, Sebba A, Gu J, et al. Comparison of tocilizumab monotherapy versus methotrexate monotherapy in patients with moderate to severe rheumatoid arthritis: the AMBITION study. Ann Rheum Dis. 2010;69:88-96.

41. Kremer JM, Blanco R, Brzosko S, et al. Tocilizumab inhibits structural joint damage in rheumatoid arthritis patients with inadequate responses to methotrexate: results from the double-blind treatment phase of a randomized placebo-controlled trial of tocilizumab safety and prevention of structural joint damage at one year. Arthritis Rheum. 2011;63:609-21.

42. Smolen JS, Beaulieu A, Rubbert-Roth A, et al. Effect of interleukin-6 receptor inhibition with tocilizumab in patients with rheumatoid arthritis (OPTION study): a double-blind, placebo-controlled, randomised trial. Lancet. 2008;371:987-97.
43. Genovese MC, McKay JD, Nasonov EL, et al. Interleukin-6 receptor inhibition with tocilizumab reduces disease activity in rheumatoid arthritis with inadequate response to disease-modifying antirheumatic drugs: the tocilizumab in combination with traditional disease-modifying antirheumatic drug therapy study. Arthritis Rheum. 2008;58:2968-80.

44. Emery P, Keystone E, Tony HP, et al. IL-6 receptor inhibition with tocilizumab improves treatment outcomes in patients with rheumatoid arthritis refractory to anti-tumour necrosis factor biologicals: results from a 24-week multicentre randomised placebo-controlled trial. Ann Rheum Dis. 2008;67:1516-23.

45. Roche Registration Ltd. RoActemra $20 \mathrm{mg} / \mathrm{ml}$ concentrate for solution for infusion. Welwynn Garden City: Roche Registration Ltd.; 2014.

46. Pappas DA, John A, Curtis JR, et al. Dosing of intravenous tocilizumab in a real-world setting of rheumatoid arthritis: analyses from the Corrona registry. Rheumatol Ther. 2016;3:103-15.

47. Townes SV, Furst DE, Thenkondar A. The impact of tocilizumab on physical function and quality of life in patients with rheumatoid arthritis: a systematic literature review and interpretation. Rheumatol Res Rev. 2012;4:87-92.

48. Fleischmann RM, Halland AM, Brzosko M, et al. Tocilizumab inhibits structural joint damage and improves physical function in patients with rheumatoid arthritis and inadequate responses to methotrexate: LITHE study 2-year results. J Rheumatol. 2013;40:113-26.

49. Gabay C, Emery P, van Vollenhoven R, et al. Tocilizumab monotherapy versus adalimumab monotherapy for treatment of rheumatoid arthritis (ADACTA): a randomised, double-blind, controlled phase 4 trial. Lancet. 2013;381:1540-1.

50. Burmester GR, Rubbert-Roth A, Cantagrel A, et al. A randomised, double-blind, parallel-group study of the safety and efficacy of subcutaneous tocilizumab versus intravenous tocilizumab in combination with traditional disease-modifying antirheumatic drugs in patients with moderate to severe rheumatoid arthritis (SUMMACTA study). Ann Rheum Dis. 2014;73:69-74.

51. Burmester GR, Rigby WF, van Vollenhoven RF, et al. Tocilizumab in early progressive rheumatoid arthritis: FUNCTION, a randomised controlled trial. Ann Rheum Dis. 2016;75:1081-91.

52. Bijlsma JW, Welsing PM, Woodworth TG, et al. Early rheumatoid arthritis treated with tocilizumab, methotrexate, or their combination (U-Act-Early): a 
multicentre, randomised, double-blind, doubledummy, strategy trial. Lancet. 2016;388:343-55.

53. Huizinga TW, Conaghan PG, Martin-Mola E, et al. Clinical and radiographic outcomes at 2 years and the effect of tocilizumab discontinuation following sustained remission in the second and third year of the ACT-RAY study. Ann Rheum Dis. $2015 ; 74: 35-43$.

54. Burmester GR, Rubbert-Roth A, Cantagrel A, et al. Efficacy and safety of subcutaneous tocilizumab versus intravenous tocilizumab in combination with traditional DMARDs in patients with RA at week 97 (SUMMACTA). Ann Rheum Dis. 2016;75:68-74.

55. Strand V, Burmester GR, Ogale S, Davenport J, John A, Emery P. Improvements in health-related quality of life after treatment with tocilizumab in patients with rheumatoid arthritis refractory to tumour necrosis factor inhibitors: results from the 24-week randomized controlled RADIATE study. Rheumatology. 2012;51:1860-9.

56. Dougados M, Kissel K, Sheeran T, et al. Adding tocilizumab or switching to tocilizumab monotherapy in methotrexate inadequate responders: 24-week symptomatic and structural results of a 2 year randomized controlled strategy trial in rheumatoid arthritis (ACT-RAY). Ann Rheum Dis. 2013;72:43-50.

57. Dougados M, Kissel K, Conaghan PG, et al. Clinical, radiographic and immunogenic effects after 1 year of tocilizumab-based treatment strategies in rheumatoid arthritis: the ACT-RAY study. Ann Rheum Dis. 2014;73:803-9.

58. Kaneko Y, Atsumi T, Tanaka Y, et al. Comparison of adding tocilizumab to methotrexate with switching to tocilizumab in patients with rheumatoid arthritis with inadequate response to methotrexate: 52 -week results from a prospective, randomised, controlled study (SURPRISE study). Ann Rheum Dis. 2016;75:1917-23.

59. Ogata A, Tanimura K, Sugimoto T, et al. Phase III study of the efficacy and safety of subcutaneous versus intravenous tocilizumab monotherapy in patients with rheumatoid arthritis. Arthritis Care Res. 2014;66:344-54.

60. Ogata A, Atsumi T, Fukuda T, et al. Sustainable efficacy of switching from intravenous to subcutaneous tocilizumab monotherapy in patients with rheumatoid arthritis. Arthritis Care Res. 2015;67:1354-62.

61. Choy E, Caporali R, Xavier R, et al. Subcutaneous tocilizumab as monotherapy or in combination with a csDMARD in patients with rheumatoid arthritis: interim analysis of a large phase IV international umbrella study, TOZURA. Ann Rheum Dis. 2017;75:509.

62. Kremer JM, Blanco R, Halland AM, et al. Clinical efficacy and safety maintained up to 5 years in patients with rheumatoid arthritis treated with tocilizumab in a randomised trial. Clin Exp Rheumatol. 2016;34:625-33.

63. Jones G, Wallace T, McIntosh MJ, Brockwell L, Gomez-Reino JJ, Sebba A. Five-year efficacy and safety of tocilizumab monotherapy in patients with rheumatoid arthritis who were methotrexate- and biologic-naive or free of methotrexate for 6 months: the AMBITION study. J Rheumatol. 2017;44:142-6.

64. Hirabayashi Y, Munakata Y, Miyata M, et al. Clinical and structural remission rates increased annually and radiographic progression was continuously inhibited during a 3-year administration of tocilizumab in patients with rheumatoid arthritis: a multi-center, prospective cohort study by the Michinoku Tocilizumab Study Group. Mod Rheumatol. 2016;26:828-35.

65. Kivitz A, Olech E, Borofsky M, et al. Subcutaneous tocilizumab vs placebo in combination with disease modifying antirheumatic drugs in patients with rheumatoid arthritis. Arthritis Care Res. 2014;66:1653-6.

66. Genovese MC, Rubbert-Roth A, Smolen JS, et al. Longterm safety and efficacy of tocilizumab in patients with rheumatoid arthritis: a cumulative analysis of up to 4.6 years of exposure. J Rheumatol. 2013;40:768-80.

67. Strangfeld A, Richter A, Siegmund B, et al. Risk for lower intestinal perforations in patients with rheumatoid arthritis treated with tocilizumab in comparison to treatment with other biologic or conventional synthetic DMARDs. Ann Rheum Dis. 2017;76:504-10.

68. Xie F, Yun H, Bernatsky S, Curtis JR. Risk of gastrointestinal perforation among rheumatoid arthritis patients receiving tofacitinib, tocilizumab, or other biologic treatments. Arthritis Rheumatol. 2016;68:2612-7.

69. Monemi S, Berber E, Sarsour K, et al. Incidence of gastrointestinal perforations in patients with rheumatoid arthritis treated with tocilizumab from clinical trial, postmarketing, and real-world data sources. Rheumatol Ther. 2016;3:337-52.

70. Espinoza F, Le Blay P, Combe B. Biologic diseasemodifying antirheumatic drug (bDMARD)-induced neutropenia: a registry from a retrospective cohort of patients with rheumatic diseases treated with 3 
classes of intravenous bDMARD. J Rheumatol. 2017;44:844-9.

71. Rubbert-Roth A, Sebba A, Brockwell L, et al. Malignancy rates in patients with rheumatoid arthritis treated with tocilizumab. RMD Open. 2016;2:e00213.

72. Frey N, Grange S, Woodworth T. Population pharmacokinetic analysis of tocilizumab in patients with rheumatoid arthritis. J Clin Pharmacol. 2010;50:754-66.

73. Abdallah H, Hsu JC, Lu P, et al. Pharmacokinetic and pharmacodynamic analysis of subcutaneous tocilizumab in patients with rheumatoid arthritis from 2 randomized controlled trials: SUMMACTA and BREVACTA. J Clin Pharmacol. 2017;57:459-68.

74. Zhang X, Peck R. Clinical pharmacology of tocilizumab for the treatment of patients with rheumatoid arthritis. Expert Rev Clin Pharmacol. 2011;4:539-58.

75. Schmitt C, Kuhn B, Zhang X, Kivitz A, Grange S. Tocilizumab has no clinically relevant effects on methotrexate pharmacokinetics in patients with rheumatoid arthritis. Int J Clin Pharmacol Ther. 2012;50:218-23.

76. Burmester GR, Choy E, Kivitz A, et al. Low immunogenicity of tocilizumab in patients with rheumatoid arthritis. Ann Rheum Dis. 2017;76:1078-85.

77. Singh JA, Saag KG, Bridges SL Jr, et al. 2015 American College of Rheumatology Guideline for the Treatment of Rheumatoid Arthritis. Arthritis Care Res. 2016;68:1-25.

78. Smolen JS, Landewe R, Bijlsma J, et al. EULAR recommendations for the management of rheumatoid arthritis with synthetic and biological diseasemodifying antirheumatic drugs: 2016 update. Ann Rheum Dis. 2017;76:960-97.

79. Shima Y, Kuwahara Y, Murota H, et al. The skin of patients with systemic sclerosis softened during the treatment with anti-IL-6 receptor antibody tocilizumab. Rheumatology. 2010;49:2408-12.

80. Elhai M, Meunier M, Matucci-Cerinic M, et al. Outcomes of patients with systemic sclerosis-associated polyarthritis and myopathy treated with tocilizumab or abatacept: a EUSTAR observational study. Ann Rheum Dis. 2013;72:1217-20.

81. Khanna D, Denton CP, Jahreis A, et al. Safety and efficacy of subcutaneous tocilizumab in adults with systemic sclerosis (faSScinate): a phase 2 , randomised, controlled trial. Lancet. 2016;387:2630-40.
82. Palard X, Querellou S, Gouillou M, et al. Value of ${ }^{18}$ F-FDG PET for therapeutic assessment in patients with polymyalgia rheumatica treated in first line by tocilizumab. Arthritis Rheumatol. 2015;67[Suppl 10] (Posters).

83. Dominguez-Casas LC, Calvo-Rio V, Blanco R, et al. Anti-IL6-R tocilizumab in refractory uveitis associated with Behçet's disease: multicenter study of 11 patients. Arthritis Rheumatol. 2015;67[Suppl 10] (Posters).

84. Kobayashi D, Ito S, Murasawa A, Narita I, Nakazono K. Two cases of adult-onset Still's disease treated with tocilizumab that achieved tocilizumab-free remission. Intern Med. 2015;54:2675-9.

85. Ortiz-Sanjuan F, Blanco R, Calvo-Rio V, et al. Efficacy of tocilizumab in conventional treatment-refractory adult-onset Still's disease: multicenter retrospective open-label study of thirty-four patients. Arthritis Rheumatol. 2014;66:1659-65.

86. Vandemergel X, Vandergheynst F. Efficacy of lowdose tocilizumab on relapsing adult-onset Still's disease. Acta Med. 2016;59:22-5.

87. Song ST, Kim JJ, Lee S, et al. Efficacy of tocilizumab therapy in Korean patients with adult-onset Still's disease: a multicentre retrospective study of 22 cases. Clin Exp Rheumatol. 2016;34[Suppl 102]:S64-71.

88. Song ST, Kim JJ, Lee S, et al. Effect of tocilizumab on adults onset still's disease in Korean population: multicenter retrospecitve study of 24 cases. Arthritis Rheumatol. 2015;67[Suppl 10] (Posters).

89. Riancho-Zarrabeitia L, Calvo-Rio V, Blanco R, et al. Tocilizumab compared with anakinra in refractory adult-onset still's disease: multicenter study of 75 patients. Arthritis Rheumatol. 2015;67[Suppl 10] (Posters).

90. Kondo T, Okada Y, Shibata A, et al. Corticosteroidfree tocilizumab monotherapy for adult onset Still's disease: results in six month. Arthritis Rheumatol. 2016;68[Suppl 10].

91. Iijima T, Suwabe T, Sumida K, et al. Tocilizumab improves systemic rheumatoid vasculitis with necrotizing crescentic glomerulonephritis. Mod Rheumatol. 2015;25:138-42.

92. Shipman L. Vasculitis syndromes: tocilizumab safe and effective for PMR. Nat Rev Rheumatol. 2016;12:374.

93. Nakaoka Y, Higuchi K, Arita Y, et al. Tocilizumab for the treatment of patients with refractory Takayasu arteritis. Int Heart J. 2013;54:405-11. 
94. Abisror N, Mekinian A, Lavigne C, Vandenhende MA, Soussan M, Fain O. Tocilizumab in refractory Takayasu arteritis: a case series and updated literature review. Autoimmun Rev. 2013;12:1143-9.

95. Mekinian A, Comarmond C, Resche-Rigon M, et al. Efficacy of biological-targeted treatments in Takayasu arteritis: multicenter, retrospective study of 49 patients. Circulation. 2015;132:1693-700.

96. Hirano T, Ohguro N, Hohki S, et al. A case of Behcet's disease treated with a humanized anti-interleukin-6 receptor antibody, tocilizumab. Mod Rheumatol. 2012;22:298-302.

97. Nishida S, Hagihara K, Shima Y, et al. Rapid improvement of AA amyloidosis with humanised anti-interleukin 6 receptor antibody treatment. Ann Rheum Dis. 2009;68:1235-6.

98. Okuda Y, Ohnishi M, Matoba K, et al. Comparison of the clinical utility of tocilizumab and anti-TNF therapy in AA amyloidosis complicating rheumatic diseases. Mod Rheumatol. 2014;24:137-43.

99. Courties A, Grateau G, Philippe P, et al. AA amyloidosis treated with tocilizumab: case series and updated literature review. Amyloid. 2015;22:84-92.

100. Lane T, Gillmore JD, Wechalekar AD, Hawkins PN, Lachmann HJ. Therapeutic blockade of interleukin6 by tocilizumab in the management of AA amyloidosis and chronic inflammatory disorders: a case series and review of the literature. Clin Exp Rheumatol. 2015;33:S46-53.

101. Umeda M, Aramaki T, Fujikawa K, et al. Tocilizumab is effective in a familial Mediterranean fever patient complicated with histologically proven recurrent fasciitis and myositis. Int J Rheum Dis. 2017;20(11):1868-71. https://doi.org/10.1111/ 1756-185X.12776

102. Hamanoue S, Suwabe T, Hoshino J, et al. Successful treatment with humanized anti-interleukin-6 receptor antibody (tocilizumab) in a case of AA amyloidosis complicated by familial Mediterranean fever. Mod Rheumatol. 2016;26:610-3.

103. Yilmaz S, Cinar M, Simsek I, Erdem H, Pay S. Tocilizumab in the treatment of patients with AA amyloidosis secondary to familial Mediterranean fever. Rheumatology. 2015;54:564-5.

104. Kluger N, Bessis D, Guillot B. Tocilizumab as a potential treatment in Schnitzler syndrome. Med Hypotheses. 2009;72:479-80.

105. Krause K, Feist E, Fiene M, Kallinich T, Maurer M. Complete remission in 3 of 3 anti-IL-6-treated patients with Schnitzler syndrome. J Allergy Clin Immunol. 2012;129:848-50.
106. Kawai M, Hagihara K, Hirano T, et al. Sustained response to tocilizumab, anti-interleukin-6 receptor antibody, in two patients with refractory relapsing polychondritis. Rheumatology. 2009;48:318-9.

107. Narshi CB, Allard SA. Sustained response to tocilizumab, anti-IL-6 antibody, following anti-TNF-alpha failure in a patient with relapsing polychondritis complicated by aortitis. Rheumatology. 2012;51:952-3.

108. Stael R, Smith V, Wittoek R, Creytens D, Mielants H. Sustained response to tocilizumab in a patient with relapsing polychondritis with aortic involvement: a case based review. Clin Rev Bone Miner Metab. 2015;34:189-93.

109. Henes JC, Xenitidis T, Horger M. Tocilizumab for refractory relapsing polychondritis-long-term response monitoring by magnetic resonance imaging. Jt Bone Spine. 2016;83:365-6.

110. Nakaoka Y, Isobe M, Takei Y, et al. Efficacy and safety of tocilizumab in patients with refractory Takayasu arteritis: results from a randomised, double-blind, placebo-controlled, phase 3 trial in Japan (the TAKT study). Ann Rheum Dis. 2018;77:348-54.

111. Sieper J, Porter-Brown B, Thompson L, Harari O, Dougados $M$. Assessment of short-term symptomatic efficacy of tocilizumab in ankylosing spondylitis: results of randomised, placebo-controlled trials. Ann Rheum Dis. 2014;73:95-100.

112. Chen C, Zhang X, Xiao L, Zhang X, Ma X. Comparative effectiveness of biologic therapy regimens for ankylosing spondylitis: a systematic review and a network meta-analysis. Medicine. 2016;95:e3060.

113. Chavele K, Gardner D, Loza MJ, et al. In vitro cellular profiling of sirukumab, an anti-IL-6 cytokine monoclonal antibody, revels a distinct phenotypic signature compared to tocilizumab, an anti-IL-6 receptor monoclonal antibody. Presented at: 2016 ACR/ARHP Annual Meeting; November 3-8, 2017; San Diego, CA (Posters).

114. Genovese MC, Fleischmann R, Kivitz AJ, et al. Sarilumab plus methotrexate in patients with active rheumatoid arthritis and inadequate response to methotrexate: results of a phase III study. Arthritis Rheumatol. 2015;67:1424-37.

115. Van Der Heijde D, van Adrichem RC, van Hoogstraten $\mathrm{H}$, et al. Clinical and radiographic outcomes after 3 years of sarilumab in patients with rheumatoid arthritis. Arthritis Rheumatol. 2016;68[Suppl 10] (Posters).

116. Genovese MC, Fay J, Parrino J, et al. Sarilumab dose reduction in an open-label extension study in RA 
patients. Arthritis Rheumatol. 2017;68[Suppl 10] (Posters).

117. Burmester GR, Lin Y, Patel R, et al. Efficacy and safety of sarilumab monotherapy versus adalimumab monotherapy for the treatment of patients with active rheumatoid arthritis (MONARCH): a randomised, double-blind, parallet-group phase III trail. Ann Rheum Dis. 2017;76:840-7.

118. Fleischmann R, Castelar-Pinheiro G, Brzezicki J, et al. Efficacy and safety of sarilumab in combination with csDMARDs in patients with active rheumatoid arthritis who were inadequate responders or intolerant of anti-TNFi \pm therapy: results from a phase 3 study. Arthritis Rheumatol. 2015;67:1424-37.

119. Strand V, Kosinski M, Graham N, et al. Impact of sarilumab on fatigue, pain, morning stiffness, productivity, and health related quality of life (HRQoL) in patients with active rheumatoid arthritis who were inadequate responders or intolerant of anti$\mathrm{TNFi} \pm$ therapy: results from a phase 3 study (RCT). Arthritis Rheumatol. 2015;67[Suppl 10] (Posters).

120. Gabay C, Msihid J, Daskalakis N, Barbot A, Zilberstein M, Boyapati A. Effect of sarilumab on circulating biomarkers of bone and joint destruction in patients with rheumatoid arthritis with previous inadequate response to tumor necrosis factor inhibitors. Arthritis Rheumatol. 2016;68[Suppl 10] (Oral presentations).

121. Emery P, Rondon J, Garg A, et al. Safety and tolerability of subcutaneous sarilumab compared to intravenous tocilizumab in patients with RA. Arthritis Rheumatol. 2015;68[Suppl 10] (Oral presentations).

122. Genovese MC, Fleischmann R, Furst D, et al. Efficacy and safety of olokizumab in patients with rheumatoid arthritis with an inadequate response to TNF inhibitor therapy: outcomes of a randomised phase IIb study. Ann Rheum Dis. 2014;73:1607-15.

123. Takeuchi T, Tanaka Y, Yamanaka H, et al. Efficacy and safety of olokizumab in Asian patients with moderate-to-severe rheumatoid arthritis, previously exposed to anti-TNF therapy: results from a randomized phase II trial. Mod Rheumatol. 2016;26:15-23.

124. Genovese MC, Fleischmann R, Tanaka Y, et al. Long-term safety and efficacy of olokizumab in patients with moderate-to-severe rheumatoid arthritis who have previously failed anti-TNF treatment. Arthritis Rheum. 2015;67[Suppl 10] (Posters).

125. Genovese MC, Durez P, Fleischman R, et al. Olokizumab treatment of both Western and Asian patients with rheumatoid arthritis who have failed anti-TNF treatment results in sustained improvements in patient-reported outcomes. Arthritis Rheumatol. 2016;68[Suppl 10] (Posters).

126. Smolen JS, Weinblatt ME, Sheng S, Zhuang Y, Hsu B. Sirukumab, a human anti-interleukin-6 monoclonal antibody: a randomised, 2-part (proof-ofconcept and dose-finding), phase II study in patients with active rheumatoid arthritis despite methotrexate therapy. Ann Rheum Dis. 2014;73:1616-25.

127. Taylor P, Schiff M, Wang Q, et al. Efficacy and safety of monotherapy with sirukumab, an anti-IL-6 cytokine monoclonal antibody, compared with adalimumab monotherapy in biologic-naive patients with active rhiematoid arthritis: results of a global randomized, double-blind, parallel-group, phase 3 study. Presented at: 2016 ACR/ARHP Annual Meeting; November 3-8, 2017; San Diego, CA (Oral presentations).

128. Chowdhury B. FDA Briefing Document: Arthritis Advisory Committee meeting. Wasington, DC: Food and Drug Administration. https://www.fda. gov/downloads/AdvisoryCommittees/ CommitteesMeetingMaterials/Drugs/ ArthritisAdvisoryCommittee/UCM569150.pdf. Accessed 14 Feb 2018

129. Weinblatt ME, Mease P, Mysler E, et al. The efficacy and safety of subcutaneous clazakizumab in patients with moderate-to-severe rheumatoid arthritis and an inadequate response to methotrexate: results from a multinational, phase $\mathrm{IIb}$, randomized, double-blind, placebo/active-controlled, dose-ranging study. Arthritis Rheum. 2015;67:2591-600.

130. Dörner T, Weinblatt $M$, Van Beneden $K$, et al. Results of a phase $2 \mathrm{~b}$ study of vobarilizumab, an anti-interleukin-6 receptor nanobody, as monotherapy in patients with moderate to severe rheumatoid arthritis. Ann Rheum Dis. 2017;76[Suppl 2]:575 